\title{
A Study on the Quality of South Kalimantan Athletes on National Student Sports Week-2019
}

\author{
Aryadi Rachman, Nurdiansyah \\ Lambung Mangkurat University \\ Banjarmasin, Indonesia \\ aryadi.rachman@ulm.ac.id
}

\begin{abstract}
This study aimed to evaluate the physical condition of the strength and endurance of athletes Pomnas South Kalimantan 2019. This study was a descriptive study with the percentage of test and measurement techniques in data collection. The population is Athlete Pre Pomnas (National Student Sports Week) from South Kalimantan 2019, amounting to 53 people. Techniques of sampling with purposive sampling is a sampling technique with specific criteria or considerations. Sample criteria used in this study were: (1) the athletes were included in contingent Pomnas from South Kalimantan in 2019, (2) have good health, (3) the condition of the athlete does not hurt or injured. The research instrument used to test and measurement of the physical condition of strength and endurance. Analysis of the data in this research is descriptive statistics. The results showed the quality of the physical condition of the strength and endurance of athletes Pomnas South Kalimantan, the quality of the physical condition of the strength and endurance of athletes Pomnas South Kalimantan overall categorized as "Very Good" only 5 athletes, the category of "Good" 27 athletes, category "Medium 38 athletes, the category of" Less "22 athletes and the category" Less than Once " 8 athletes.
\end{abstract}

\section{Keywords: evaluation, physical strength, endurance}

\section{INTRODUCTION}

Achievement is the goal of every athlete in any sport, but for achievement requires hard work and consistency in practice. Many are several factors that accomplishments can be achieved, ranging from technical factors, tactics, physical condition, psychology. Elements of the physical conditions required in each sport are different. An athlete needs to increase through the exercise carried out systematically and continuously. Through physical exercise, physical fitness athletes will be increased to support the achievement of optimal performance [1]. The physical condition is a unified whole of components which cannot be separated without either increase or maintenance [2]. This means that in efforts to improve the physical condition then all components must be developed,

The elements or components of the physical condition include strength (strength), durability (endurance), explosive power, speed, resilience, agility, coordination, balance, accuracy and reaction. One important component of physical condition in order to support the other components is a component of muscle strength [2]. Strength is the basis of all the components of the physical condition because power is the driving force of any physical activity [2]. Maximum power is strongly influenced by seven factors, namely: (1) The number of motor units involved (recruitment). (2) The number of motor units is stimulated (rate coding). (3) The number of motor unit's synchronization. (4) Cycle shortening of the muscle stretch. (5) The degree of inhibition of the muscle nerve. (6) This type of muscle fibres. (7) The degree of muscle hypertrophy [3-4]. In addition to the strength of the physical condition, of course, there is the component that is important in every sport that is a component of physical condition durability. Durability is the body's ability to perform activities/work within a period without experiencing significant fatigue, accompanied by a rapid recovery [5]. The term endurance or durability in the sport known as organ sportsman equipment capabilities to fight fatigue during activity or work [6]. A person who has good durability then the person can do the exercise duration, and intensity of work is high. Durability is the body's ability to perform activities/work within a period without experiencing significant fatigue, accompanied by a rapid recovery [5]. The term endurance or durability in the sport known as organ sportsman equipment capabilities to fight fatigue during activity or work [6]. A person who has good durability then the person can do the exercise duration and intensity of work is high. Durability is the body's ability to perform activities/work within a period without experiencing significant fatigue, accompanied by a rapid recovery [5]. The term endurance or durability in the sport known as organ sportsman equipment capabilities to fight fatigue during activity or work [6]. A person who has good durability then the person can do the exercise duration and intensity of work is high. The term endurance or durability in the sport known as organ sportsman equipment capabilities to fight fatigue during activity or work [6]. A person who has good durability then the person can do the exercise duration and intensity of work is high. The term endurance or durability in the sport known as organ sportsman equipment capabilities to fight fatigue during activity or work [6]. A person who has good durability then the person can do the exercise duration and intensity of work is high.

In general, any elements or components of the physical condition but the components need to be trained endurance and strength are very important to be trained first. In this study, the research Fokos only on the evaluation of physical strength and endurance athletes in preparing for the quality of an athlete to achieve high performance.

\section{METHOD}

The research method in this study is a quantitative descriptive approach. The quantitative method called traditional method because this method is long enough to use, so it's been a tradition, as a method for research. The method is as scholarly or scientific method possible because it has met scientific principles, namely concrete or empirical, objective, measurable, rational and systematic. This method is also called quantitative because the research data in the form of figures and statistical analysis using [7]. 
TABLE III. PUSH TEST

\begin{tabular}{|l|l|l|}
\hline \multicolumn{3}{|c|}{ Push Tests } \\
\hline Norm & Result & Percentage (\%) \\
\hline Very well & 0 & 0 \\
\hline Well & 0 & $0: 00$ \\
\hline Moderate & 8 & $15: 09$ \\
\hline Less & 24 & 45.28 \\
\hline Less than Once & 21 & 39.62 \\
\hline Amount & 53 & 100 \\
\hline
\end{tabular}

- To test Pull Up category of "Very Good" as much as 1 athlete (2\%), the category of "Good" by 11 athletes $(21 \%)$, category "Medium" as many as 19 athletes (36\%), the category of "Less" as many as 16 athletes $(30 \%)$, category "Less than once" as many as six athletes $(11 \%)$.

TABLE IV. PULl TEST

\begin{tabular}{|l|l|l|}
\hline \multicolumn{3}{|c|}{ Pull tests } \\
\hline Norm & Result & Percentage (\%) \\
\hline Very well & 1 & 1.89 \\
\hline Well & 11 & 20.75 \\
\hline Moderate & 19 & 35.85 \\
\hline Less & 16 & 30.19 \\
\hline Less than Once & 6 & $11: 32$ \\
\hline Amount & 53 & 100 \\
\hline
\end{tabular}

- To test Handgrip Right category of "Very Good" as many as 3 athletes (6\%), the category of "Good" by 24 athletes (45\%), category "Medium" as many as 21 athletes $(40 \%)$, the category of "Less" by 5 athletes $(9 \%)$.

TABLE V. RIGHT HANDGRIP TEST

\begin{tabular}{|l|l|l|}
\hline \multicolumn{3}{|c|}{ Right Handgrip test } \\
\hline Norm & Result & Percentage (\%) \\
\hline Very well & 3 & 5.66 \\
\hline Well & 24 & 45.28 \\
\hline Moderate & 21 & 39.62 \\
\hline Less & 5 & $9: 43$ \\
\hline Less than Once & 0 & 0 \\
\hline Amount & 53 & 100 \\
\hline
\end{tabular}

- To test Handgrip Left category of "Very Good" by 10 athletes (19\%), the category of "Good" by 23 athletes (43\%), category "Medium" as many as 19 athletes (36\%), the category of "Less" by 1 athlete (2\%).

TABLE VI. LEFT HANDGRIP TEST

\begin{tabular}{|l|l|l|}
\hline \multicolumn{3}{|c|}{ Left Handgrip test } \\
\hline Norm & Result & Percentage (\%) \\
\hline Very well & 10 & 18.87 \\
\hline Well & 23 & 43.40 \\
\hline Moderate & 19 & 35.85 \\
\hline Less & 1 & 1.89 \\
\hline Less than Once & 0 & 0 \\
\hline Amount & 53 & 100 \\
\hline
\end{tabular}

- For the tests of Durability Cardiac Pulmonary, category of "Very Good" by 4 athletes (7\%), the category of "Good." by 4 athletes (7\%), category "Medium" as many as 30 athletes (57\%), the category of "Less" a total of 12 athletes (23\%), the category "Less than once" as many as 3 athletes (6\%). 


\section{REFERENCES}

TABLE VII. DURABILITY CARDIAC PULMONARY TEST

\begin{tabular}{|l|l|l|}
\hline \multicolumn{3}{|c|}{ Endurance Test } \\
\hline Norm & Result & Percentage (\%) \\
\hline Very well & 4 & 7.55 \\
\hline Well & 4 & 7.55 \\
\hline Moderate & 30 & 56.60 \\
\hline Less & 12 & 22.64 \\
\hline Less than Once & 3 & 5.66 \\
\hline Amount & 53 & 100 \\
\hline
\end{tabular}

\section{CONCLUSION}

The conclusion states the quality of the physical condition of the strength and endurance of athletes Pomnas from South Kalimantan overall categorized as "Very Good" only 5 athletes, the category of "Good" 27 athletes, category "Medium 38 athletes, the category of" Less "22 athletes and the category" Less than Once athlete.
[1] Rachman, A. 2014. Effects of Exercise Squat and Leg Press Strength and Hypertrophy Muscle of Limbs. Journal multilateral, 13(2), 88-102.

[2] Sajoto. 1995. Enhancement and Development of Physical Strength dalam Olahraga. Semarang: Dahara Prize

[3] Bompa, T.O. and Haff, G.G. 2009. Periodization Theory and Methodology of Training. United States. Human Kinetics.

[4] Hoeger, W.W.K. \& Hoeger, S.A. 2009. Lifetime Physical Fitness and Wellness: A Personalized Program, Tenth Edition. USA; Wadsworth, Cengage Learning.

[5] Sidik, D.Z., Pesurnay, P.L., and Afari L. 2019. Training Physical Condition. Bandung: PT Young Rosdakarya.

[6] Sukadiyanto. 2011. Pengantar Teori dan Metodologi Melatih Fisik. Bandung: Lubuk Agung

[7] Sugiono. 2005. Non Parametik Statistics. Bandung: Al Fabeta 